\title{
Network security analysis from the perspective of "we-media"--taking the influence of ideological and political education in colleges and universities as an example
}

\author{
Tong Lin* \\ Northwestern Polytechnical University, Xi'an 710072, PR China
}

Keywords: We-Media, Network security, Ideological and political education.

\begin{abstract}
Although "We-media" appeared earlier in foreign countries, its emergence in our country is relatively recent. It has the characteristics of commonality, low registration cost and fast information dissemination, which is favored by people of all ages, especially young people. The rise of "We-media" not only brings development opportunities to network security, but also can expand the scope of influence for publicizing network security credibility to a certain extent. However, at the same time, it also brings new challenges to network security. As a college educator, the author tries to analyze network security dialectically from the perspective of "We-media", so as to further explain its influence on ideological and political education in colleges and universities. How to effectively manage the application and implementation of "We-media" and maintain a good network security environment is an important topic we will face in the current and future period.
\end{abstract}

\section{Introduction: the emergence, meaning and characteristics of "we-media" in China}

"We-Media" is a very popular word now. What is the meaning "We-media"? In 2003, the media center of the American press association gave a more rigorous definition of "We-Media", that is, "We-media" is "a way for the general public to begin to understand how they can provide and share their own facts and their own news, after they have been enhanced by digital technology and connected with the global knowledge system." In 2004, Dan Gilmer, an American IT columnist, divided the generation into old and new media in his monograph "We-media: grassroots news, from the masses, for the masses". In his opinion, "1.0" refers to traditional media or old media, "2.0" refers to new media, and "3.0" refers to We-media. The author believes that although the latter two have similarities in carrier or media, "We-media"

*Corresponding author: lintong@nwpu.edu.cn 
has its own distinctive characteristics, which are embodied in the fact that "We-media is different from TV, newspaper and other media forms in the past, and has its own unique network ecological environment"[1]. However, both the definition of "We-media" by the media center of the American press association and the generational division of the old and new media by the American IT columnist Dan Gilmer are behaviors at the beginning of this century. Can they be applied to the second era of the 21 st century that is coming to an end? In addition, in recent years, are micro-blogs, including WeChat and even small videos such as Tik Tok also belong to the category of "We-media"?

According to the American press association's Media center's explanation of the key factors involved in the definition of "We-media" in 2003, as well as the author's understanding of the "immediacy" of "We-media" and the "facts" and "news" involved, it can be considered that micro-blogs, WeChat, Tik Tok, etc. that have emerged recently in China belong to "We-media", and a "3.0" (We-media) era different from "1.0" (traditional media or old media) and "2.0" (new media) has arrived. At present, "We-media" in China has the following characteristics:

1. Civilian. There is almost no cost to register "We-media". As long as you are willing, almost everyone can become the subject of using "We-media". Therefore, "different from the one-way communication of traditional media, every participant in the social chain of" We-media "will filter the obtained information and express it in his own way before spreading it again. Everyone is a journalist and editor, and everyone is a media subject."

2. Low cost. When using "We-media", an account can be obtained by filling in the most basic personal information at the time of registration, which can be reviewed by the operator of "We-media". It is basically a form of audit. Once the audit is successful, We-media platforms can be used to produce, disseminate and comment on relevant information [2].

3. The speed of information dissemination is high, the advantages and disadvantages coexist, but the advantages outweigh the disadvantages. Just because We-media has the characteristics of commonality and low cost of use, almost everyone can participate as long as he/she is willing. Information of dissemination value can be widely spread within a short period of time, which is an advantage. Because "disseminators of information can selectively send some content in line with their own intentions, so as to achieve the purpose of de-theming, de-centralizing and influencing specific groups"[3]. Therefore, some "We-media" users will directly fabricate relevant facts, which is the major disadvantage.

4. It has greatly enriched people's lives and is favored by people of all ages, especially young people. Although the information spread by "We-media" and some subjects make vulgar, even illegal and deviant behaviors to attract attention, it really enriches people's life and is favored by most people.

As a conclusion, the rise of "We-media" and its wide application, despite some negative phenomena such as rampant false information, it is undeniable that the advantages outweigh the disadvantages. The state should strengthen the monitoring of public opinions and timely release some normative documents that can effectively regulate the development of "We-media", so as to achieve sustainable and healthy development on the premise of conforming to the basic provisions of laws and basic moral standards.

\section{Opportunities and challenges brought to network security by the rise of we media}

The network regime is the core of network sovereignty, and the safety of Internet users is the core of the network regime. Inviolability of Internet sovereignty means inviolability of Internet regime. We Media is gradually rising. Its responsibility and obligation is to guard the security of the network regime. The rise of the We Media has promoted the construction of 
network security to a certain extent. In other words, it has brought opportunities to network security. The application of We Media is free. However, this freedom is not the reason to violate the security of the network regime, but to guarantee of the security of the network regime. That is to say, freedom and security depend on each other and complement each other. Security brings freedom, and freedom also brings security. The application of We Media contains various network ideologies. Only on the basis and premise of mainstream ideology can the safety of network ideology be guaranteed. The core of safeguarding the security of network ideology is to safeguard political power, national sovereignty and network sovereignty. General Secretary Xi Jinping stressed: Publicity and reporting should be carried out around readers and audiences, and propaganda and ideological work should also focus on readers and audiences. Therefore, only by making full use of mainstream media to publicize the positive energy of society can we ensure the credibility and safety of mainstream media on the network, thus effectively guiding the development direction of We Media application and promoting network security.

However, We Media is civilian. The cost of making content, disseminating and paying attention to its content is low, and the speed of information dissemination is beyond comparison. This characteristic has won the favor of people of all ages, especially young people. Because of this, to some extent, it has intensified the complexity and diversity of the ideological field and brought severe challenges to network security. Take the ideological and political education in colleges and universities as an example. Apart from educators, there are almost all young students. Their daily expenses for schooling and living are basically borne by their families, although they are already adults. Therefore, students in school can be said to have no worries about food and clothing, relatively abundant time, and always have curiosity about new things. Specifically, the application of We Media in colleges and universities is characterized by:

1. Few people would like to create works, while most people tend to spread, forward or comment on them. For We Media platforms such as WeChat moment and QQ Space, when they are used, they are usually used to publish shorter life feelings, or slightly longer essays, diaries and other words, or pictures taken and collected by themselves. Basically, it is to express the mood at a certain moment. These behaviors are rarely original, and most of them are forwarding and commenting. For We Media platforms such as small videos such as Tik Tok, when they are used, they usually upload their own videos, or make some photos into dynamically played videos, or think that the videos made by others are interesting and exquisite, and then increase the attention of their accounts by forwarding them. Some of the subjects who often use such videos dream of becoming "Internet celebrities" or "talents". These behaviors are generally more original and less forwarded and commented.

2. As there are not many cases that seriously affect life and study, schools need to pay more attention to them. There are people who use We Media at all ages. However, it is an undeniable fact that the majority of users are young people including students in school. A vital reason is that they are in a golden age of growth, with strong curiosity and ability to accept new things. Nevertheless, whether produced or forwarded, the works uploaded on We Media platform are more eye-catching, especially those that have already attracted great attention. This tends to induce users of We Media to find it difficult to stop in a short period of time once log in, thus affecting their normal study and life. The scale of "phubbing" people is increasing day by day. Through observation, it can be found that people who frequently look at their mobile phones are mostly brushing WeChat moment, instead of simply looking at the time or waiting for people to reply to WeChat. This kind of behavior has even become the unconscious behavior of many people and is difficult to "quit" in a short period of time. Moreover, WeChat has the greatest influence and users among all We Media at present, and also has the greatest influence on the daily life and study of young people, including students 
in school. For the phenomenon of "Phubbing" or "Phone Freak", the main body, including colleges and universities, should pay attention to it and adopt legal and reasonable methods to regulate it.

3. The potential of college educators to carry out ideological and political education on students with the help of We Media needs to be explored. When We Media is used to frequently forward work-related information, it is difficult to call it pure We Media again especially when this kind of behavior becomes the norm. For college educators, there are not many people who use We Media as "official media". First, college educators are worried that they may forward inappropriate information and then "get into trouble" and assume unexpected responsibilities. Second, they are often rather busy and have no time to carefully produce works to publicize the college's work of their own. Third, every school and college has its own official website and public micro-signals, and even more than one public micro-signal. Each department has staff specially responsible for news gathering and editing, who make, push and forward corresponding information and then play a role in publicizing the department. Ordinary staff, if they intend to use their We Media accounts to publicize their own departments or disseminate information related to their own departments, can directly forward the ready-made news on their own websites. This is also based on the realistic need to unify the "caliber". Then, relatively speaking, as a college educator, it is unrealistic to collect news, collect information, send high-standard written works, picture works, video works, etc. to their own We Media, and then make a contribution to the publicity of the college. This is also unrealistic in terms of technology, cost, time, energy and "one department, one voice". By the same token, for college educators, it is difficult to expect them to frequently use their We Media platform for work including ideological and political education, but it does not mean that there is no potential worth tapping.

In conclusion, We media which mainly includes WeChat (including WeChat public account) and Tik Tok has developed rapidly with great influence and many users. However, by observing We Media users in colleges and universities, we can find that: first, most people who use We Media are to record the dribs and drabs of life. Secondly, users are to forward or share some information related to learning. Thirdly, the user is to forward work-related information in order to publicize the department they are working for. Even though, it is relatively rare to apply We Media to the development of ideological and political education, its potential is worth paying attention to and tapping. In general, "the fragmentation of We Media's discourse expression, communication and interaction has profoundly affected the cognitive style and behavior choice of contemporary college students. We Media brings realistic challenges to the ideological and political education in colleges and universities. At the same time, it also provides new carriers and new fields for the ideological and political education in colleges and universities[4].

\section{Maintaining the balance between the development of we media and network security}

Considering that the development of We media is an important part of network security, safeguarding the security of the We media platform means safeguarding network security. With the increasing dependence of users on We media, We media will not only become an important field for network public opinion, but also have an important impact on network security. Consequently, it is necessary to further balance the relationship between the development of We media and network security, and deeply grasp the generation mechanism and development characteristics of We media platform, thus establishing a scientific and rational processing mechanism to correctly guide the development of We media and ensure network security. As far as the ideological and political education in colleges and universities 
is concerned, one of the consequences of the arrival of the We media era is that "ideological and political educators no longer have the advantage of information, and sometimes even fall into the embarrassing situation of collective aphasia[5]." However, this consequence cannot be allowed to continue to expand. On the contrary, ideological and political education should be reformed with the times by tightly grasping the benefits that We media platforms can bring. Specifically, the exploration can be implemented from the following three aspects:

1 In terms of university educators, they should be advocated and encouraged to register two WeChat Official Accounts, with one for life and the other for work, and this proposal is not aimed at the number of WeChat Official Accounts, but to facilitate them to effectively separate life and work. In particular, all educators should actively forward positive information generated in the college, while for negative information, relevant workers should also forward appropriate investigation results or official announcements, so as to stop rumors spreading. Meanwhile, counselors, teachers of ideological and political education as well as relevant leaders in charge of students' ideological work should also actively screen important documents such as decisions, regulations, resolutions and other important documents formulated by Party committees and governments from the central to local levels on promoting ideological and political education in colleges and universities.

2 In terms of students in university, they should be required to subscribe at least the WeChat accounts of counselors and the teachers who are responsible for their ideological and political education courses. At the same time, for student cadres and party members as well as students who hold corresponding positions, they should also subscribe at least the WeChat accounts of the leaders in charge of ideological work of students. Basically, this is to provide a platform for students to learn ideological and political education. However, there is no mandatory requirements for students to praise, comment or forward WeChat moments for ideological and political educators. Because mandatory requirements are not only easy to be suspected of violating students' personal privacy, but also meaningless.

3 Under normal circumstances, each college has its own WeChat official accounts. Therefore, the counselors, leaders in charge of students' ideological work and student cadres in corresponding positions can be required to participate in the operation and management of official accounts on a regular basis, especially to compile news or related information for ideological and political education.

Additionally, it is worth mentioning that "college" is the basic unit in universities. Therefore, it can be used as a unit to explore how to apply We media to various tasks including ideological and political education. Furthermore, "ideological and political education" needs to be expanded and explained, including all behaviors beneficial to the education of politics, rule of law, morality, culture for students in university. It is inappropriate to simply limit the "ideological and political education" to "political education".

\section{Summary}

The arrival of the Internet era in our country is later than that in other countries, which leads to the emergence of We media in our country later as well. However, in recent years, the development of We media platforms represented by WeChat has been quite strong, deeply affecting the daily life of people of all ages, especially young people with strong curiosity and ability to accept new things. In other words, it can also be said that "the widespread use of media is one of the most prominent features of the current information age, and it is also the crystallization of the development of Internet technology to the second generation[6]." However, it should be noted that from the perspective of We media, the intersection and overlap of numerous "Moments" of WeChat have constructed the public space and social 
network in which people live. On one hand, this process not only promoted the formation of popular communication channels, but also promoted the deep integration of the mass and media, on the other hand, the new opportunities and challenges it brings to network security also need us to analyze and grasp dialectically. In order to create a good public opinion field for network security and further explore a reasonable path to play its beneficial role to the greatest extent, college educators must strengthen the rational application of We media platform and fully mobilize the enthusiasm of all parties, as well as dig deeply into the development evolution, so as to do a good job in ideological and political education in universities under the new situation.

\section{References}

1. K. Ding, G. Song. Innovation of University Education Network Construction in Self-media Era. Journal of Ideological and Theoretical Education, 2014(6):112-115.

2. J. Fan. Correspondence, Fission and Energy Accumulation: Socialist Core Values Education in Colleges and Universities under We media Ecology. Theory Guide, 2016(9):93-95.

3. X. Jiang. Multidimensional Analysis of the Causes of Current College Students Affected by Internet Political Rumors. Ideological and Political Education Research, 2017(4):105-108.

4. R. Duan. Challenges of Fragmentation of We Media to Ideological and Political Education in Colleges and Universities and Their Countermeasures. Party Building and Ideological Education in Schools, 2018(8):47-49.

5. X. Ren, Q. Shen. Research on We Media and Innovation Path of Ideological and Political Education for College Students. China Youth Research, 2014(7):106-109.

6. Z. Wu. The 'Instrumental' Crisis and Governance of Ideological and Political Education Applied by We Media. Heilongjiang Higher Education Research, 2019(4):135-139. 